Jurnal Gizi dan Dietetik Indonesia (Indonesian Journal of Nutrition and Dietetics) Vol. 8, No. 2, 2020: 87-92
Available online at: http://ejournal.almaata.ac.id/index.php/IJND DOI : http://dx.doi.org/10.21927/ijnd.2020.8(2).87-92

\title{
A nutrition diary-book effectively increase knowledge and adherence of iron tablet consumption among adolescent female students
}

\author{
Jurianto Gambir ${ }^{1}$, Iman Jaladri ${ }^{1}$, Endah Mayang Sari², Yulinda Kurniasari ${ }^{*}$ \\ ${ }^{1}$ Department of Nutrition, Poltekkes Kemenkes Pontianak Jalan 28 Oktober Siantan Hulu Pontianak, \\ Kota Pontianak Kalimantan Barat \\ ${ }^{2}$ Department of Nutrition, Poltekkes Kemenkes Pangkal Pinang, Jalan Pulau Bangka, Padang Baru, \\ Kec. Pangkalan Baru, Kabupaten Bangka Tengah, Kepulauan Bangka Belitung \\ ${ }^{3}$ Department of Nutrition, Faculty of Health Sciences, Universitas Alma Ata, Jalan Brawijaya No. 99 \\ Yogyakarta, Indonesia \\ *Corresponding author: kurniasari.yulinda@almaata.ac.id
}

\begin{abstract}
ABSTRAK
Latar Belakang: Edukasi gizi yang tepat dapat merubah remaja putri untuk berperilaku hidup sehat. Inovasi program edukasi yang dapat memotivasi remaja putri dalam mencari dan mengkonsumsi tablet zat besi secara teratur sangat dibutuhkan sehingga dapat menurunkan prevalensi anemia di Indonesia. Tujuan: Mengetahui pengaruh edukasi melalui buku diary gizi terhadap pengetahuan gizi, minat mencari tablet zat besi dan kepatuhan remaja putri dalam mengkonsumsi tablet zat besi (Fe).

Metode: Quasi experimental (Non-Randomized group pre-post test) study dengan 50 subyek penelitian yang terbagi menjadi dua kelompok perlakuan. Subjek penelitian adalah siswi remaja putri di SMA di Kota Pontianak, dengan kriteria umur 14-16 tahun sudah haid dan bersedia menjadi subjek penelitian. Intervensi berlangsung selama dua bulan efektif. Kelompok intervensi diberikan tablet zat besi (Fe) + buku Diary Gizi dan kelompok kontrol tanpa buku Diary Gizi. Tablet zat besi (Fe) yang diberikan mengandung 60 $\mathrm{mg}$ Fe elemental dan $20 \mathrm{mg}$ asam folat. Data dianalisis menggunakan software komputer dan disajikan dalam bentuk tekstular dan table, dengan uji statistik Chi square dan t test.

Hasil: Hasil penelitian program suplementasi zat besi (Fe) dikalangan remaja putri belum popular. Tingkat pengetahuan siswi yang mendapatkan edukasi gizi dengan Buku Diary lebih baik dibandingkan dengan siswi yang mendapatkan edukasi melalui penyuluhan $(p<0,05)$. Siswi dari kelompok buku Diary Gizi lebih patuh dalam mengkonsumsi tablet zat besi $(p<0,05)$.

Kesimpulan: Pemberian dan aktivitas dengan catatan harian buku Diary Gizi dapat digunakan dalam meningkatkan pengetahuan dan meningkatkan kepatuhan remaja putri dalam mengkonsumsi tablet zat besi (Fe). Penggunaan Buku Diary Gizi dapat dipertimbangkan dalam mensukseskan program suplementasi zat besi $(\mathrm{Fe})$ pada remaja putri
\end{abstract}

KATA KUNCI: buku diary gizi; kepatuhan; konsumsi; pengetahuan; remaja putri; tablet zat besi (Fe)

\begin{abstract}
Background: Proper education about nutrition can change adolescent females to have a healthy lifestyle. Innovation of education programs which can motivate female adolescents in finding and consuming iron tablets regularly is highly necessary, so that it can decrease the prevalence of anemia in Indonesia.

Objectives: To find out the effect of Nutrition Diary-Book education on nutritional knowledge, effort to find iron tablets and consuming iron tablets in adolescence.

Methods: A quasi experimental study (non-randomized group pre-post test) was conducted with 50 subjects divided into two groups. The age of the subjects were 14-16 years old, already had menstruation and were willing to be research subjects for 2 months. Iron tablets and nutrition diary-books were administered to intervention group and were administered to control group without nutrition diary-books. The results were analyzed using chi square and t-test.

Results: The level of knowledge who get education about nutrition by having nutrition diary-books is better compared to female students who get the education through elucidation $(p<0.05)$. The female students
\end{abstract}


from the intervention group were proven to be more obedient in consuming iron tablets $(p<0.05)$.

Conclusion: The administration of nutrition diary-book and activity of writing nutrition diary-book can be used to increase knowledge and adherence in consuming iron tablets among adolescent female students.

KEYWORDS: adherence; adolescent; iron tablet; knowledge; nutrition diary-book

Article info:

Article submitted on April 12, 2020

Articles revised on May 20, 2020

Articles received on June 9, 2020

\section{INTRODUCTION}

Anemia is one of the most important health problems throughout the world (1); (2) (3); (4). Anemia is considered the most common nutritional deficiency worldwide and in $95 \%$ of cases it is associated with an iron poor diet. The WHO estimates that around two billion individuals worldwide, over $30 \%$ of the world's population, are anemic, highlighting the importance of anemia as a public health issue in both developing and developed nations $(3,5,6)$. Study in Malaysia found that $59.6 \%$ of adolescents suffered from anemia, $44 \%$ female and $15,2 \%$ male (7). Several research results in Indonesia found that $40 \%$ female adolescents in Lampung suffered from anemia (8) and $21 \%$ of adolescents in Bogor (4).

During adolescence, anemia is estimated to be the greatest nutritional problem. Anemia in adolescents and young adults can have negative effects on their cognitive performance and growth. If pregnancy occurs during adolescence, anemia can not only increase maternal morbidity and mortality, but increase the incidence of poor birth outcomes in the infant and also negatively impact infant iron status (9); (10); (11).

Combating anemia in female adolescents was by increasing iron supplementation. Indonesian government has conducted an iron supplementation program on female adolescents aged 12-18 years old in school but it was not thoroughly conducted in all schools. Lack of knowledge can affect nutritional status due to the limitation of information implementation about nutrition and health in daily life. The effort of increasing knowledge can be conducted through nutritional education as early as possible (12).
Several studies stated that nutritional education was effective in increasing knowledge about nutrition (13); (14). A study in Semarang nutritional education increases knowledge and students' attitude of having a balanced diet. The average or knowledge before nutritional education was $66.46 \%$ it was increased to $71.61 \%$ after intervention. The method of nutritional status can be through elucidation, giving poster, leaflet or booklet to students (12).

Nutritional elucidation by using the media of bulletin and mural art was effective to increase knowledge of elementary students about obesity (15). The increase of knowledge through comics is more effective than without comics (16). Novel was effective for healthy life-style promotion among all overweight and obese adolescents (17). Nutritional education using storybooks can improve nutrition knowledge in female adolescents (18).

Education through books read by mothers to babies appearing about knowledge from birth to 12 months of age (eg, injury prevention, parenting, nutrition) when the infants were approximately 2 , $4,6,9,12$, and 18 months of age. Books read by mothers to babies appear to be an effective way to provide anticipatory guidance to new mothers (19). Study in pediatric patients with ALL in a pediatric oncology center in Yogyakarta, Indonesia. Medication diary book might be useful for patients with ALL in resource limited settings, especially with highly educated mothers (20).

\section{MATERIALS AND METHODS}

The design of this study was an experimental equation (non-randomized group pre-posttest). The subjects of the research were 50 female students 
in State High School 5 Pontianak, Indonesia. The subjects were divided into two groups each group consisting of 25 people. Sampling was conducted by using a purposive sampling method, with criteria of age 14-16 years, has menstruation and be willing to participate in research. The intervention was conducted for two months. Iron tablet and nutrition diary-book was administered to one group and iron tablet was administered to another group without a nutrition diaries book. The iron tablets given contain $60 \mathrm{mg}$ Fe elemental and $20 \mathrm{mg}$ folic acid. The nutrition diary-book is specifically designed; it contained program information, anemia in adolescence and the recommendation to consume iron tablets regularly. In addition, subjects can fill notes in the nutrition diarybook. The data were analyzed by computer software and used statistical tests, chi square tests, paired sample tests and independent t-tests. Ethical approval for this study was obtained from Health Polytechnic Makassar No. 167/KEPK-PTKMKS/IV/2017

\section{RESULTS}

As many as $70 \%$ of the study subjects was reported having irregular menstruation each month (Table 1).
Table 1. Depiction of menstruation on samples

\begin{tabular}{ccc}
\hline \multicolumn{1}{c}{ Variables } & Numbers & $\begin{array}{c}\text { Percentage } \\
(\%)\end{array}$ \\
\hline Regularities of period each month & \\
Regular & 15 & 30.0 \\
Irregular & 35 & 70.0 \\
First year of having menstruation (year) & \\
$10-11$ & 28 & 56.0 \\
$12-14$ & 21 & 42.0 \\
$\geq 15$ & 1 & 2.0 \\
The period of having menstruation (day) & \\
$4-6$ & 26 & 52.0 \\
$7-8$ & 24 & 48.0 \\
\hline
\end{tabular}

More than $50 \%$ of subjects spend the first time in 10-11 years with a period of 5-6 days. More than $80 \%$ of the samples never looked for iron tablets, but more than $60 \%$ of the samples in the diary group purchased iron ( $\mathrm{Fe}$ ) tablets or took them at the health center when they were told to do so, whereas in the elucidation group of about $60 \%$ the samples were not willing to buy substance tablets iron, but are willing to take it at the Health center when they were told to do so (Table 2).

The average knowledge of the diaries / intervention group or elucidation group increased after the intervention was given, with a difference

Table 2. The attitude of subjects in consuming iron (Fe) tablet

\begin{tabular}{lcccc}
\hline \multicolumn{1}{c}{ Variables } & \multicolumn{2}{c}{ Diary Book } & \multicolumn{2}{c}{ Elucidation } \\
& Number & Percentage (\%) & Number & Percentage (\%) \\
\hline The effort to find iron tablet & 4 & 16.0 & 3 & 12.0 \\
$\quad$ Ever & 21 & 84.0 & 22 & 88.0 \\
$\quad$ Never & & & & \\
$\quad$ Willingness to buy iron tablet & 17 & 68.0 & 9 & 36.0 \\
$\quad$ Willing & 8 & 32.0 & 16 & 64.0 \\
$\quad$ Unwilling & & & & \\
Availability in health center & 5 & 20.0 & 9 & 36.0 \\
$\quad$ Want to take, because it is important & 17 & 68.0 & 14 & 56.0 \\
$\quad$ Want to take, if be asked & 3 & 12.0 & 2 & 8.0 \\
$\quad$ Do not want to & & & & \\
\hline
\end{tabular}

Table 3. Average Nutrition Knowledge Before and After Intervention in the Diary and Counseling Groups

\begin{tabular}{|c|c|c|c|c|c|c|}
\hline \multirow{2}{*}{ Variables } & \multicolumn{2}{|c|}{ Diary Book } & \multicolumn{2}{|c|}{ Elucidation } & \multirow{2}{*}{$\mathrm{p}$-value } & \multirow{2}{*}{$t$} \\
\hline & Before & After & Before & After & & \\
\hline knowledge & $7.08 \pm 1.95$ & $\begin{array}{l}10.56 \\
\pm 9.08\end{array}$ & $7.88 \pm 198$ & $\begin{array}{c}8.55 \pm \\
1.75\end{array}$ & 0.00 & 3,912 \\
\hline Good knowledge(\%) & 24.4 & 76.0 & 9.0 & 12.0 & 0.04 & 3,097 \\
\hline
\end{tabular}


Table 4. Average consumption of iron tablet after intervention on diary group and elucidation group

\begin{tabular}{lcccc}
\hline Variables & $\begin{array}{c}\text { Diary book } \\
\text { average } \pm \text { SD }\end{array}$ & $\begin{array}{c}\text { Elucidation } \\
\text { average } \pm \text { SD }\end{array}$ & p-value & $\mathrm{t}$ \\
\hline Iron tablet consumption & $14.52 \pm 4.13$ & $9.76 \pm 4.82$ & 0.00 & 3,922 \\
Iron tablet consumption $\geq 60 \%(\%)$ & 32 & 4 & 0.01 & 3,730 \\
\hline
\end{tabular}

of 3.48 points in the diary group and 0.67 points in the extension group $(p<0.05)$ (Table 3 ).

The average consumption of iron tablets in the diary group was more, which was 14.52 tablets compared to the extension group at 9.67 tablets ( $p$ $<0.05$ ) (Table 4).

\section{DISCUSSION}

The study aimed to increase the knowledge and adherence of female adolescents to consume iron tablets, through education with diary books, evidenced by the average knowledge and adherence to consumption of the diary book group increased significantly after the intervention $(p<0.05)$. specifically designed to contain information about the problem of anemia in young women as well as the negative effects caused if a young woman experiences anemia. The pouring of notes in a nutrition diary is intended to remind young women to consume iron tablets. When writing besides getting knowledge about the problem of anemia, it is also a strategy to remind female adolescents to consume iron ( $\mathrm{Fe}$ ) tablets. The significant difference in behavior in the diary book group is a positive impact of the intervention.

The increase of knowledge was far higher in nutritional diary groups. This provides an understanding of nutrition education with diary books to have a better impact on improving adolescent nutrition knowledge than comparing education through elucidation. From the total research subjects as many as two female students with almost perfect score in answering the whole question and the two adolescent came from the diary group.

The results of this study are in line with the findings of (15) that the use of tools, in the form of media in the learning process has a close relationship in increasing students' knowledge and learning achievement. Effective provision of nutrition education through booklets increases the average iron intake of female adolescent by $15.5 \mathrm{mg}$ (21). Direct involvement of adolescent in learning will increase passion and enthusiasm in learning, easier to understand a topic of problems. The use of pleasant educational learning resources will stimulate new interest, motivation that is closely related to students' psychology(16).

The learning process helps students to understand and present data that is interesting, reliable and capable of compacting information. Knowledge, attitudes and skills are not affected by age and level of education but are affected by peer education interventions. Based on the results of these studies, it is necessary to optimize the female peer group who already exist in the community, integrating efforts to promote and prevent anemia problems into the program (22).

In this study the adherence to consuming iron tablets using $60 \%$ cut off point or consuming $\mathrm{Fe}$ tablets for at least 15 tablets for two months. The results showed that the group of young women diary books were significantly more obedient in consuming iron $(\mathrm{Fe})$, which was $32.0 \%$ in the diary book group and $4.0 \%$ in the control group ( $p<0.05 \%$ ). The disobedience of female students in consuming iron $(\mathrm{Fe})$ tablets is caused by forgetfulness, fear, forbidden by parents, complaints of side effects such as nausea, dizziness and smell.

The behavior of consuming iron tablets for young women is not too popular among the commoners, so this will be an important issue of concern to better socialize and improve education for female students. Young females are candidates for a mother who has childbirth so they need proper health preparation, when they want to get pregnant and during pregnancy. Women of childbearing age who have anemia have a low birth weight 
(LBW) and are closely related to the incidence of stunting in children. Hence Nutrition Education and supplementation should be able to improve iron status of adolescents, so that after marriage they can enter serious iron-deficiency handicaps (23).

The practices carried out by students in consuming iron tablets according to the recommendations of the Indonesian Ministry of Health with 13 tablets per month. There is an average increase in the number of tablets consumed by both groups in each month, however, the number of tablets consumed is higher in the nutrition education group through diary books, both the first month and the second month. Statistical tests showed that there were significant differences in the average number of tablets consumed in both groups $(p<0.05)$.

Research in Gatak Subdistrict, Sukoharjo district, stated that nutrition education had an effect on increasing adherence to iron tablets consumption through the class of pregnant women (24). Research in Sumedang District found that the effect of SMS Reminder as providing information in increasing adherence with iron $(\mathrm{Fe})$ tablets(24). Nutrition education using storybooks can improve nutrition knowledge in young women(18).

The weakness of this study is that evaluating the impact of the study only focused on the end of the study, paying less attention to mid-intervention, so that the prohibition of parents to consume iron tablets was not detected earlier and greatly influenced the behavior of iron tablets consumption of research subjects.

\section{CONCLUSION AND RECOMMENDATION}

The level of knowledge and adherence of the education group students by using diary books was better than the elucidation group. Female students from the education group with diary books had a more positive or good response in finding iron tablets compared to the elucidation group.

\section{REFERENCES}

1. Yasemin Işık Balcı* $M$, Aysun Karabulut $M$, Dolunay Gürses M, İbrahim Ethem Çövüt M.
Prevalence and Risk Factors of Anemia among Adolescents in Denizli,Turkey. 2012; Vol 22 (No(1):77-81.

2. Mulugeta A, Tessema M, Hsellasie K, Seid O, Kidane G, Kebede A. Examining means of reaching adolescent girls for iron supplementation in Tigray, Northern Ethiopia. Nutrients. 2015;7(11):9033-45.

3. Bezerra AGN, Leal VS, Lira PIC de, Oliveira JS, Costa EC, Menezes RCE de, et al. Anemia e fatores associados em mulheres de idade reprodutiva de um município do Nordeste brasileiro. Rev Bras Epidemiol [Internet]. 2018;21(0):1-13. Available from: http://www.scielo.br/scielo.php?script=sci_ arttext\&pid=S1415-790X2018000100400\&Ing $=$ pt\&tlng=pt

4. Permatasari T, Briawan D, Madanijah S. Efektivitas Program Suplementasi Zat Besi pada Remaja Putri di Kota Bogor. 2018;14(1):1-8.

5. Zimmermann MB, Hurrell RF. Nutritional iron deficiency. Lancet. 2007;370:511-20.

6. Cairo RC de A, Silva LR, Bustani NC, Marques CDF. Iron deficiency anemia in adolescents; a literature review. Nutr Hosp. 2014;29(6):1240-9.

7. Yusoff H, Wan Daud WN, Ahmad Z. Effectiveness of nutrition education vs. non-nutrition education intervention in improving awareness pertaining iron deficiency among anemic adolescents. Iran J Public Health [Internet]. 2013;42(5):467-71. Available from: http://ijph.tums.ac.ir

8. Martini. Faktor - Faktor Yang Berhubungan Dengan Kejadian Anemia Pada Remaja Putri Di Man 1 Metro. J Kesehat Metro Sai Wawai. 2016;2(1):34-44.

9. Chaparro CM. Anemia among adolescent and young adult women in Latin America and the Caribbean: A cause for concern. World Heal Organ [Internet]. 2008;11. Available from: http://www.paho.org/hq/dmdocuments/2010/ AnemiaEngWEB.pdf

10. Yusoff H, Daud WNW, Ahmad Z. Nutrition education and knowledge, attitude and hemoglobin status of Malaysian adolescents. Southeast Asian J Trop Med Public Health. 2012;43(1):192-200. 
11. Baxter JAB, Wasan Y, Soofi SB, Suhag Z, Bhutta ZA. Effect of life skills building education and micronutrient supplements provided from preconception versus the standard of care on low birth weight births among adolescent and young Pakistani women (15-24 years): A prospective, population-based cluster-ran. Reprod Health. 2018;15(1):1-9.

12. Nuryanto, Pramono S, Puruhita N, Muis $S$. Pengaruh pendidikan gizi terhadap pengetahuan dan sikap tentang gizi anak Sekolah Dasar. J Gizi Indones. 2015;3(1):1858-4942.

13. Zulaekah S. Pendidikan Gizi Dengan Media Booklet Terhadap Pengetahuan Gizi. J Kesehat Masy. 2012.

14. Bertalina. Pengaruh Promosi Kesehatan Terhadap Peningkatan Pengetahuan Tentang Gizi Seimbang Pada Siswa Sekolah Dasar Negeri Di Kecamatan Rajabasa Kota Bandar Lampung. J Kesehat [Internet]. 2015;6(1):5663. Available from: http://poltekkes-tjk.ac.id/ ejurnal/index.php/JK/article/view/26

15. Riswanti I. Media Buletin Dan Seni Mural Dalam Upaya Meningkatkan Pengetahuan Tentang Obesitas. J Heal Educ [Internet]. 2016;1(1):6270. Available from: http://journal.unnes.ac.id/sju/ index.php/jhealthedu/

16. Hamida K, Zulaekah S, Mutalazimah. Paradigma dan Model Penelitian Komunikasi. J Kesehat Masy [Internet]. 2014;2(1):352-3. Available from: http://academicjournals.org/journal/AJFS/ article-abstract/2202A3A53892\%5Cnhttp:// journal.unnes.ac.id/nju/index.php/ kemas\%5Cnhttp://journal.fk.unpad.ac.id/ index.php/mkb/article/view/127\%5Cnhttp:// www.ik.pom.go.id\%5Cnhttp://ik.pom. go.id\%5Cnhttp://ww
17. Bravender T, Russell A, Chung RJ, Armstrong SC. A "Novel" Intervention: A Pilot Study of Children's Literature and Healthy Lifestyles. Pediatrics [Internet]. 2010;125(3):e513-7. Available from: http://pediatrics.aappublications. org/cgi/doi/10.1542/peds.2009-1666

18. Rohim A, Zulaekah S, kusumawati Y. Perbedaan Pengetahuan Anemia Pada Remaja Putri Setelah Diberi Pendidikan Dengan Metode Ceramah Tanpa Media Dan Ceramah Dengan Media Buku Cerita. J Kesehat. 2016;1(2):411-21.

19. Reich S, Bickman L, Saville B, Alvarez J. The Effectiveness of Baby Books for Providing Pediatric Anticipatory Guidance to New Mothers. 2010;125(5):997-1002.

20. Sitaresmi M, Mostert S, Gundy C, Ismail D, Veerman A. A Medication Diary-Book for Pediatric Patients With Acute Lymphoblastic Leukemia in Indonesia. Pediatr Blood Cancer. 2013;53(December 2008):13-6.

21. Marfuah D, Kusudaryati DPD. The Effectiveness of Nutrition Education on Improving Iron Intake in Teenage Daughter. Profesi. 2016;14(September):5-9.

22. Aisah S, Sahar J, Hastono S. Pengaruh Edukasi Kelompok Sebaya Terhadap Perubahan Perilaku Pencegahan Anemia Gizi Besi pada Wanita Usia Subur di Kota Semarang. J Keperawatan. 2008;Vol.2 No.1.

23. Kaur M, Bassi R, Sharma S. Impact Of Nutrition Education In Reducing Iron Deficiency Anemia In Adolescent Girls. Indian J Fundam Appl Life Sci. 2011;1(4):222-8.

24. Sulastijah S, Helmyati S. Pengaruh pendidikan gizi dalam upaya meningkatkan kepatuhan konsumsi zat besi melalui kelas ibu hamil. J Gizi Klin Indones. 2015;12(02):79-87. 